\title{
PERLINDUNGAN KONSUMEN TERHADAP PERJANJIAN JUAL BELI PERUMAHAN PRESPEKTIF UNDANG-UNDNAG NOMOR 1 TAHUN 2016 TENTANG PERUMAHAN DAN KAWASAN PEMUKIMAN
}

\author{
Nurzamzam \\ Fakultas Hukum Universitas Borneo Tarakan \\ Jalan Amal lama Nomor 1 Tarakan \\ Email : zamzam.law@gmail.com \\ Mardiana \\ Fakultas Hukum Universitas Borneo Tarakan \\ Jalan Amal lama Nomor 1 Tarakan
}

\begin{abstract}
The need for housting is increasing every year in Indonesia. Many events of laws and acts of laws that will accur in the business of housing, for example the sale and purchase, case this will potentially give birth to the issue of law which is great if it did not hace an umbrella law that is clearly to provide protection to kosumen of the perpetrators of the business that is not faith either in business housing.

Indonesia has made a regulatory law that can be used as a handle to the consumers, is with the birth of Law Number 8 Year 1999 on Protection of Consumers, which regulate the right and obligatuins business actors as well as consumers and Law no.1 of 2011 concerning Housing and Setttlement Areas and their plementing regulations. However, from the perspective of Law no.1 of 2011 concerning Housing and Settlement Areas has not actually been able to protect consumers rights so as to harm the community as consumers
\end{abstract}

Key words : legal protection ; sale and purchase ; housing

\begin{abstract}
Abstrak
Kebutuhan akan perumahan semakin meningkat setiap tahunnya di Indonesia. hal ini akan berpotensi melahirkan persoalan hukum yang besar jika tidak memiliki payung hukum yang jelas untuk memberikan perlindungan kepada kosumen dari pihak pelaku usaha yang tidak beritikad baik dalam menjalangkan bisnis perumahan. Indonesia telah membuat peraturan perundang-undangan yang dapat dijadikan pegangan terhadap konsumen, yakni dengan lahirnya Undang-undang Nomor 8 Tahun 1999 tentang Perlindungan Konsumen, yang mengatur mengenai hak dan kewajiban pelaku usaha serta konsumen dan Undang-Undang No. 1 Tahun 2011 tentang Perumahan dan Kawasan Permukiman beserta peraturan pelaksanaannya. Namun dari perspektif Undang-Undang No. 1 Tahun 2011 tentang Perumahan dan Kawasan Permukiman belum secara nyata dapat melindungi hak-hak konsumen sehingga merugikan masyarakat selaku konsumen.
\end{abstract}

Kata kunci : perlindungan hukum; jual beli; perumahan 


\section{Borneo Law Review Vol.4 No.2 \\ Desember2020}

\section{PENDAHULUAN}

A. Latar Belakang Masalah

Indonesia di sepuluh tahun terakhir mengalami pertumbuhan ekonomi yang cukup baik. Hal ini menyebabkan kebutuhan akan perumahan bukan lagi sekedar pemenuhan kebutuhan akan tempat tinggal bagi masyarakat yang memang belum memiliki rumah. Namun saat ini motif kepemilikan rumah terlah bergeser sebagai salahsatu jenis investasi yang cukup menjanjikan keuntungan yang besar dibandingkan investasi lain. Berbagai kebijakan pemrintah lahir terkait hal tersebjut misalnya dengan lahirnya program rumah bersubsidi.

Kebijakan ini kemudian ditindaklanjuti oleh pemerintah daerah dalam bentuk ajakan kepada para pengembang property untuk membangun perumahan di wilayah mereka. Pengemban kemudian bekerjasama dengan pihak perbankan yang menyediakan fasilitas kredit investasi dibidang perumahan atau Kredit Kepemilikan Rumah (KPR), dengan tujuan sebuah rumah akan lebih mudah untuk dijual. Ketika masyarakat kemudian sepakat mengikatkan dirinya dalam perjanjian KPR tersebut maka disinilah lahir hubungan hukum antara pengembang dan konsumen dalam bentuk perjanjian jual beli perumahan yang berpotensi besar melahirkan persoalan hukum baru dalam bidang perlindungan konsumen.

Badan Perlindungan Konsumen Nasional (BPKN) sejak September 2017 lalu hingga saat ini,menerima pengaduan berkisar 400-500 kasus pengaduan. ${ }^{1}$ Sebanyak 348 kasus adalah sektor perumahan. Berdasarkan data yang dihimpun oleh BPKN, banyak kasus-kasus perumahan yang menimbulkan ketidakpastian hukum, seperti iklan yang menyesatkan, pemahaman konsumen atas perjanjian atau kontrak yang tidak memadai, cara pembayaran dengan kredit pemilikan rumah (KPR), status tanah yang tidak jelas dan klausula baku yang mengalihkan tanggung jawab, ketidakjelasan adanya sertifikat, serta perjanjian dan dokumen yang menjadi jaminan kredit. ${ }^{2}$. pengaduan ini timbul jelas karna adanya pihak yang merasa di rugikan.

Persoalan ini akan bermuara pada penegakan Undang Undang No 8 tahun 1999 tentang Perlindungan Konsumen dan akan erat hubunganya Undang Undang Nomor 1 tahun 2011 tentang Perumahan dan Kawasan Pemukiman juga ditambah dengan Peraturan Pemerintah nomer 14 tahun 2016 tentang Penyeleanggaraan perumahan dan Kawasan perumahan.

\footnotetext{
${ }^{1}$ https://hukumonline.com/ Selasa 18 Desember 2019“masalah perumahan paling banyak diadukan perumahan"di akses tanggal 6 Mei 2020

${ }^{2}$ Risma Riyadi https://www.ayobandung.com/read/2019/04/08/49122/perumahan-jadi-masalahterbanyak-yang-diadukan-konsumen. Diakses tanggal 6 Mei 2020
} 


\section{Borneo Law Review Vol.4 No.2}

Desember2020

B. Rumusan Masalah

Berdasarkan uraian latar belakang di atas maka permasalahan yang dingkat dalam penelitian ini adalah sebagai berikut :

1. Peran pemerintah dalam proses pembangunan perumahan dan Kawasan pemukiman dalam Upaya perlindungan Konsumen

2. Perspektif UU No.1 Tahun 2011 tentang Perumahan dan Kawasan Permukiman terhadap perlindungan hak-hak konsumen dalam jual beli perumahan

\section{METODE PENELITIAN}

Penelitian ini menggunakan pendekatan yuridis-normatif, yaitu dengan melakukan inventarisasi hukum positif yang terkait dengan pembangunan perumahan dan Kawasan pemukiman. Kemudian diurai secara deskriptif-analitis dengan jalan menggambarkan secara rinci, sistimatik, dan menyeluruh mengenai segala hal yang berhubungan upaya perlindungan konsumen serta analisis terhadap aspek hukum yang berkaitan dengan tanggungjawab negara dalam hal ini pemerintah terhadap masalah-masalah perlindungan dalam bidang jual beli perumahan.

Sumber data yang dibutuhkan meliputi data primer, yaitu pandangan, sikap, atau persepsi Pemerintah dan masyarakat mengenai upaya perlindungan konsumen khusunya di wilayah penelitian, Di samping itu, juga menggunakan data sekunder yang diperoleh dari bahan hukum primer dan bahan hukum sekunder. Data yang diperoleh kemudian dianalisis secara kualitatif 3 , yaitu data sekunder yang berupa teori, definisi dan substansinya dari berbagai literatur, dan peraturan perundang-undangan, serta data primer yang diperoleh dari wawancara, observasi dan studi lapangan, kemudian dianalisis dengan undang-undang, teori dan pendapat pakar yang relevan, sehingga didapat kesimpulan tentang upaya perlindungan konsumen diwilyah penelitian.

\section{HASIL PENELITIAN DAN PEMBAHASAN}

Hukum perlindungan konsumen cukup mendapatkan perhatian karena menyangkut aturan-aturan guna mensejahterakan masyarakat, bukan saja masyarakat selaku konsumen namun pelaku usaha juga mendapatkan perlindungan dengan menempatkan keduanya sebagai subjek yang masing-masing memilki hak dan kewajiban. Pemerintah berperan mengatur, mangawasi dan mengontrol sehingga tercipta system kondusif yang saling berkaitan satu

${ }^{3}$ Soerjono Soekanto, 2006, Pengantar Penelitian Hukum, Penerbit UI Press, , h. 250 


\section{Borneo Law Review Vol.4 No.2 Desember2020}

dengan yang lainnya dengan demikian tujuan mensejahterkan masyarakat secara luas dapat tercapai.

Menurut Az. Nasution yang dikutip oleh Celina Tri Siwi K, menyatakan bahwa 4"Hukum perlindungan konsumen merupakan bagian dari hukum konsumen yang lebih luas. Asas-asas dan kaidah-kaidah hukum yang mengatur hubungan dan masalah konsumen itu tersebar dalam berbagai bidang hukum baik tertulis maupun tidak tertulis, seperti hukum perdata, hukum dagang, hukum pidana, hukum administrasi (negara) dan hukum internasional terutama konvensi-konvensi yang berkaitan dengan kepentingan kepentingan konsumen."Berkaitan dengan Permasalahan dalam bisnis perumahan pada umumnya menempatkan konsumen selalu berada pada posisi yang lemah ${ }^{5}$.keberadaan UUPK serta peraturan perudang undangan yang lain menjadi harapan terbesar saat ini dalam mewujudkan perlindungan konsumen dan tentu masih terbuka kemungkinan terbentuknya undnag-undang baru yang pada dasarnya memutar ketentuan-ketentuan yang melindungi konsumen.

\section{A. Peran Pemerintah dalam proses pembangunan perumahan dan Kawasan pemukiman dalam Upaya perlindungan Konsumen}

Hubungan antara konsumen, pelaku usaha dan pemerintah yang seimbang menjadi harapan bagi terwujudnya perlindungan komnsumen di Indonesia. Pasal 2 UUPK $^{6}$ menyebutkan bahwa perlindungan konsumen berasaskan manfaat, keadilan, keseimbangan, keamanan dan keselamatan konsumen serta kepastian hukum.

Tujuan perlindungan konsumen itu sendiri diatur dalam Pasal 3 UUPK yang secara umum adalah meningkatkan kesadaran serta kemanpuan konsumen serta harkat dan martbatnya. Melalui system perlindungan. Konsumen Juga mengatur pelaku usaha untuk bersikaf jujur dan bertanggung jawab terhadap konsumen. Guna mewujudkan perlindungan konsumen yang salahsatunya terkait dengan papan masyarakat, pemerintah memiliki peran dengan menggunakan system pengawas dan Pembinaaan yang efektif. Pembinaan diatur dalam Pasal 29 UUPK yang menyebutkan bahwa:

"Pemerintah bertanggungjawab atas pembinaan penyelenggaraan perlindungan konsumen yang menjamin diperolehnya hak konsumen dan pelaku usaha serta dilaksanakannya kewajiban konsumen dan pelaku usaha."

\footnotetext{
${ }^{4}$ Celina Tri Siwi Kristiyanti, Hukum Perlindungan Konsumen, Jakarta: Sinar Grafika 2009, hlm. 13

${ }^{5} \mathrm{Ni}$ Ketut Dewi Megawati, 'PERSPEKTIF UNDANG-UNDANG NOMOR 1 TAHUN 2011 TENTANG PERUMAHAN DAN KAWASAN PERMUKIMAN Magister Hukum Udayana •', Magister Hukum Udayana, 5.1 (2016), 12-22.

${ }^{6}$ Pemerintah Republik Indonesia, 'Undang-Undang Nomer 8 Tahun 1999 Tentang Perlindungan Konsumen', Undang - Undang Perlindungan Konsumen (UUPK), 1999.
} 
Pengawasan sebagaimana dimaksud dalam Pasal 30 UUPK adalah sebagai berikut: Pengawasan terhadap penyelenggaraan perlindungan konsumen serta penerapan ketentuan peraturan perundang-undangannya diselenggarakan oleh pemerintah, masyarakat, dan lembaga perlindungan konsumen swadaya masyarakat. Bentuk peran serta pemerintah dalam melakukan pembinaan dan pengawasan terhadap pembangunan perumahan dan Kawasan pemukiman ditandai dengan lahirnya UndangUndang No. 1 tahun 2011 tentang Perumahan dan Kawasan Pemukiman (UUPKP) ${ }^{7}$ dan Perturan Pemerintah No. 14 Tahun 2016 tentang penyelenggaraan Perumahan dan Kawasan Pemukiman. Di dalam ketentuan pasal 5 UUPKP

1. Negara bertanggung jawab atas penyelenggaraan perumahan dan kawasan permukiman yang pembinaannya dilaksanakan oleh pemerintah.

2. Pembinaan sebagaimana dimaksud pada ayat (1) dilaksanakan oleh:

a. Menteri pada tingkat nasional;

b. gubernur pada tingkat provinsi; dan

c. bupati/walikota pada tingkat kabupaten/kota.

Kemudian dalam Pasal 6 Pembinaan sebagaimana dimaksud dalam Pasal 5 ayat (2) meliputi: Perencanaan, pengaturan, pengendalian; dan pengawasan. Kemudian dilanjutkan di pasal 10 bahwa pengawasan yang dimaksud adalah meliputi pemantauan, evaluasi, dan koreksi sesuai dengan ketentuan peraturan perundang-undangan. Ketentuan peraturan perundang udangan ini meliputi perizinan termasuk di dalamnya Izin mendiringan bangunan yang wajib di milki oleh pengembang sebelum melaksanakan pembangunan perumahan.

Pembangunan perumahan dan kawasan permukiman yang bertumpu pada masyarakat memberikan hak dan kesempatan seluas-luasnya bagi masyarakat untuk ikut berperan. Sejalan dengan peran masyarakat di dalam pembangunan perumahan dan kawasan permukiman, Pemerintah dan Pemerintah Daerah mempunyai tanggung jawab untuk menjadi fasilitator, memberikan bantuan dan kemudahan kepada masyarakat, serta melakukan penelitian dan pengembangan yang meliputi berbagai aspek yang terkait antara lain: tata ruang, pertanahan, prasarana lingkungan, industri bahan dan komponen, jasa konstruksi dan rancang bangun, pembiayaan, kelembagaan, sumber daya manusia, kearifan lokal, serta peraturan perundang-undangan yang mendukung8

\footnotetext{
${ }^{7}$ Government of the Republic of Indonesia, Undang-Undang Nomor 1 Tahun 2011 Tentang Perumahan Dan Kawasan Pemukiman, 2011.

${ }^{8}$ Sulaiman, 'Kata Kunci: Tanggung Jawab, Pemerintah, Penyediaan Tanah, Perumahan Dan Masyarakat Berpenghasilan Rendah (MBR) . 1', 2011, 1-29.
} 


\section{Borneo Law Review Vol.4 No.2 Desember2020}

Peraturan perundang-undangan atau regulasi yang dibuat baik di tingkat pusat maupun di daerah harus saling terintegrasi satu sama lain. Dengan begitu upaya meminimalisis kerugian yang berpotensi terjadi terhadap kosumen dalam hal jual beli perumahan di setiap wilayah di Indonesia dapat diminimalisir. Kegiatan penataan dan kendali pemerintah terhadap berabgai kegiatan kehidupan kemasyarakatan termasuk di dalamnya pembuatan peraturan perundang-undangan, pemberian izin, pengadaan perencanaan merupakan bagian dari upaya mewujudkan perlindungan bagi konsumen di Indonesia

\section{B. Perspektif UU No.1 Tahun 2011 tentang Perumahan dan Kawasan Permukiman terhadap perlindungan hak-hak konsumen dalam jual beli perumahan}

Ketidaksesuain antara apa yang tercantum dalam penawaran dengan barang atau rumah yang diterima konsumen merupakan peristwa hukum yang paling sering terjadi dalam transaksi jual beli perumahan di Indonesia. Dalam usaha menarik konsumen, iklan terkadang berlebihan atau tidak sesuai dengan barang yang dijual. Iklan yang menyesatkan banyak dijumpai di berbagai media massa maupun sarana promosi yang dibuat oleh pelaku usaha property, dengan tujuan untuk memastikan bahwa unit rumah yang mereka bangun dapat terjual sebelum perumahan tersebut selesai. Hal ini dilakukan oleh pengembang salahsatu faktornya adalah modal yang mereka gunakan untuk membangun bersumber dari pembiayaan lembaga keuangan atau bank sehingga semakin lama suatu unit perumahan terjual maka beban bunga terhadap pinjaman yang telah diambil akan semakin besar.

Larangan terhadap hal tersebut telah diatur dalam pasal 134 UU No.1 Tahun 2011 tentang. Perumahan dan Kawasan Permukiman

"Setiap orang dilarang menyelenggarakan pembangunan perumahan, yang tidak membangun perumahan sesuai dengan kriteria, spesifikasi, persyaratan, prasana, sarana, dan utilitas umum yang diperjanjikan."

Permasalahan dalam bisnis perumahan pada umumnya menempatkan konsumen dalam posisi yang lemah. Sulisstyowati melihat 6 poin penting yang merugikan konsumen, dalam upaya mendapatkan perumahan, yaitu ${ }^{9}$

a. semakin tingginya harga rumah;

b. para pengembang swasta enggan membangun rumah jenis sederhana, karena darasakan keuntungan yang akan didapat sangat kecil

c. pengembang sering tidak memperhatikan kepentingan para konsumen, dengan mengangkari janji akan penyediaan sarana dan prasarana umum;

\footnotetext{
${ }^{9}$ SulIstyowatI, 1992, Akses Kepada Perlindungan Konsumen Sebagai Salah Satu Aspek Kesejahteraan Sosial, Jakarta, Universitas Indonesia, hlm.20.
} 
d. keadaan keadaan perumahan senyatanya tidak sesuai dengan yang dijanjikan;

e. kualitas rumah yang buruk ; dan

f. administarsi cicilan BTN yang tidak rapi

Kurangnya pengetahuan konsumen akan hak-haknya sebagai seorang warganegara Republik Indonesia sering disalahgunakan oleh pengembang perumahan dalam menyediakan perumahan serta lingkungan yang memenuhi syarat. Kerugian ini banyak dialami oleh konsumen yang membeli rumah di perumahan komersial. Seiring meningkatnya jumlah penduduk yang relatif banyak, maka dewasa ini pertumbuhan perumahan pun relative semakin meningkat ${ }^{10}$

Dihubungkan dengan hal tersebut perlindungan hukum terhadap konsumen perumahan di Indonesia masih lemah sehingga perlu keterlibatan seluruh pemegang kebijakan atau institusi baik yang berada di level pusat maupun di tingkat daerah untuk secara bersama menjadi pengayom persoalan konsumen perumahan. hingga saat ini belum memiliki sistem dan peraturan yang terintegrasi dan jelas untuk menjadi solusi efektif persoalan konsumen. Berbagai regulasi yang mengatur tentang perumahan berada di lintas kementrian dan daerah. Misalnya dalam hal peruntukan sebidang tanah.

Lembaga Negara yang diberikan kewenangan untuk hal tersebut adalah Badan Pertanahan Nasional berdasarkan Undang-Undang nomor 5 Tahun 1960 Tentang Ketentuan Pokok Agraria guna penertbitan sertifikat dan menentukan peruntukan sebidang lahan tersebut atas rekomendasi pemerintah daerah. Dalam hal pemanfaatan lahan melalui Ijin Mendirikan Bangunan (IMB) yang dikeluarkan oleh Kabupatan/ Kota mengacu kepada Perda tentang Rencana Tata Ruang dan Wilayah (Perda RTRW) disetiap Kabupaten/Kota. Kasus yang sering terjadi sertifikat yang terbit peruntukannya adalah perumahan tetap namun pada saat pengajuan IMB, Pemerintah Kabupaten/Kota menilai bahwa tanah tersebut peruntukannya adalah Ruang Terbuka Hijau Kota sesuai dengan Perda RTRW setempat. Hal ini besar kemungkinan terjadi karena ketidak tegasan peraturan perundang-undangan mengatur fungsi dan wewenang masing- masing jenjang pemerintah. Hal ini akan menimbulkan ketidakpastian hukum yang pada akhirnya akan merugikan konsumen.

Dalam UU No. 8 Tahun 1999 dan UU No. 1 Tahun 2011 telah mengatur tentang hak dan kewajiban konsumen dan pengembang perumahan. Bahkan untuk mengurangi pelanggaran hak konsumen dalam UU No. 1 Tahun 2011 telah melibatkan Pemerintah Provinsi dan Pemerintah Kabupaten/Kota untuk mengurus dan mengawasi pengadaan perumahan dan

\footnotetext{
${ }^{10}$ Edi As' Adi, 2011, Hukum Proyek Konstruksi Bangunan (Dalam Perspektif Pelayanan Publik yang Baik di Indonesia), Yogyakarta, Graha Ilmu, hlm. 2
} 


\section{Borneo Law Review Vol.4 No.2 Desember2020}

kawasan permukiman di masing-masing wilayahnya seperti yang tertuang dalam pasal 12 sampai pasal 18 yang mengatur tugas dan kewenangan Pemerintah, Pemerintah Provinsi, dan Pemerintah Kabupaten/Kota

Pengaturan tentang hak konsumen dalam UU No. 1 Tahun 2011 tertuang dalam pasal 129 dan 130. Dalam ranah perlindungan konsumen, hak bagi konsumen adalah kewajiban yang harus dipenuhi oleh pelaku usaha. Pelanggaran atas kewajiban dari pelaku usaha merupakan pelanggaran atas hak konsumen. Guna menghindari hal tersebut, ditentukan oleh pemenuhan kewajiban dari pelaku usaha tetapi pihak konsumen perumahan juga harus jeli dan teliti dalam memilih perumahan berkualitas dengan pengembang yang bertanggungjawab. Pengalaman serta nama baik pengembang menjadi variabel yang amat penting dalam transaksi perumahan dalam menjamin terpenuhinya semua hak konsumen.

Pengembang yang sudah memiliki rekam jejak baik dan sudah memiliki pengalaman yang panjang di bisnis perumahan akan tetap menjaga reputasi yang sudah mereka bangun sangat lama karena dalam bisnis apapun terutama bisnis perumahan yang melibatkan sumber daya modal yang sangat besar kepercayaan adalah hal yang sangat penting. Konsumen juga wajib terlebih dahulu menelusuri secara teliti dan benar sebelum memutusakan membeli rumah atau property. Iklan yang ditawarkan oleh para pengembang harus diteliti kebenarannya sehingga kerugian sebagai konsumen dapat diminimalisir

\section{PENUTUP}

\section{A. Kesimpulan}

Indonesia telah membuat peraturan perundang-udangan yang dapat dijadikan pegangan terhadap konsumen, yakni dengan Undang-undang Nomor 8 Tahun 1999 tentang Perlindungan Konsumen, yang mengatur mengenai hak dan kewajiban pelaku usaha serta konsumen begitupun juga dengan lahirnya UU No. 1 Tahun 2011 tentang Perumahan dan Kawasan Permukiman serta ditambah dengan Peraturan Pemerintah nomer 14 tahun 2016 tentang Penyeleanggaraan perumahan dan Kawasan perumahan. Namun kemudian belum terintegrasi secara baik dan belum dilaksanakan secara tegas dalam pelaksanaannya dengan lembaga lain dan di daerah, sehingga dinilai kurang memberikan perlindungan dan kepastian hukum bagi konsumen.

UU No. 1 Tahun 2011 tentang Perumahan dan Kawasan Permukiman belum secara nyata dapat melindungi hak-hak konsumen dalam bisnis perumahan sehingga mengakibatkan praktek-praktek bisnis perumahan yang berkembang merugikan masyarakat selaku konsumen. Ditambah lagi regulasi yang tidak saling terintegrasi satu sama lain yang berkaitan dengan peruntukan tanah pemukiman baik ditingkat pusat maupun di tingkat daerah 


\section{B. Saran}

Pemerintah pusat dan pemerintah daerah baik ditingkat provinsi maupun kabupaten kota sebagai pemegang kebijakan serta yang memliki cukup kekuasaan sanagt penting untuk saling bekerjasama dengan baik dalam menata kembali peraturan perundang-undangan atau regulasi yang berkenaaan dengan bisnis perumahan agar dapat menjamin rasa keadialn serat perlindungan hukum bagi konsumen. Terlidungainya secara penuh hak hak konsumen dari segala bentuk bisnis yang tidak beritikad baik akan turut menyumbang kemajuan kehiduoan yang layak bagi masyarakat bangsa dan Negara

Masyarakat sebagai konsumen juga wajib menjadi konsumen yang cerdas dengan menggunakan hak dan kewajibannya sebagai konsumen sebelum kemudian memtuskan untuk melakukan perjanjian jual beli perumahan. Teliti sebelum membeli akan meminimalisir kerugian sebagai konsumen.

\section{DAFTAR PUSTAKA}

Edi As' Adi, 2011, Hukum Proyek Konstruksi Bangunan (Dalam Perspektif Pelayanan Publik yang Baik di Indonesia), Yogyakarta, Graha Ilmu

Celina Tri Siwi Kristiyanti, Hukum Perlindungan Konsumen, 2009. Jakarta: Sinar Grafika Megawati, Ni Ketut Dewi, 'PERSPEKTIF UNDANG-UNDANG NOMOR 1 TAHUN 2011 TENTANG PERUMAHAN DAN KAWASAN PERMUKIMAN Magister Hukum Udayana •', Magister Hukum Udayana, 5.1 (2016), 12-22

Sulaiman, 'Kata Kunci: Tanggung Jawab, Pemerintah, Penyediaan Tanah, Perumahan Dan Masyarakat Berpenghasilan Rendah (MBR) . 1', 2011, 1-29

Soerjono Soekanto, , Pengantar Penelitian Hukum, 2006 Penerbit UI Press

SulIstyowatI, 1992, Akses Kepada Perlindungan Konsumen Sebagai Salah

Satu Aspek Kesejahteraan Sosial, Jakarta, Universitas Indonesia

Suyadi, . Dasar-Dasar Hukum Perlindungan Konsumen. 2007 Purwokerto: UNSOED

PERATURAN PERUNNDANG UNDANGAN

Undang-Udnnag Dasar Negara Indonesia tahun 1945

Kitab Undang Undang Hukum Perdata

Undang Undang Nomor 8 tahun 1999 tentang Perlindungan Konsumen

Undang-Undang Nomor 1 Tahun 2011 tentang Perumahan dan kawasan Pemukiman

Peraturan pemerintah Nomor 14 tahun 2016 tentang Penyelenggaraan Perumahan dan Kawasan Pemukiman 
Borneo Law Review Vol.4 No.2

Desember2020

WEBSITE ONLINE

https://hukumonline.com/

https://www.ayobandung.com

tribunkaltim.com 